\title{
Grain Yield of Malt Barley (Hordium Vulgare L.) Production as Influenced by Nitrogen Split-Application Timing in Central Highlands of Ethiopia
}

\author{
Legesse Admassu Sakatu Hunduma
}

\begin{abstract}
This experiment was initiated to evaluate the appropriate nitrogen fertilizer split application timing for malt barley. This experiment was done at Holeta Agricultural Research center, West Shoa, Ethiopia. The split nitrogen application times were $1 / 2$ at planting $+1 / 2$ at mid tillering, $1 / 2$ at planting $+1 / 2$ at anthesis, nil at planting $+1 / 2$ mid tillering $+1 / 2$ at anthesis, nil at planting + full at mid tillering, nil at planting + full at anthesis, $1 / 2$ at planting $+2 / 3$ at mid tillering, $1 / 3$ at planting $+1 / 3$ mid tillering $+1 / 3$ at anthesis, nil at planting $+1 / 3$ mid tillering $+2 / 3$ at anthesis, $2 / 3$ at planting $+1 / 3$ mid tillering, $2 / 3$ at planting $+1 / 3$ at anthesis, full at planting and negative control. The experiment was laid out randomized complete block design with three replications. Timing of split nitrogen fertilizer applications has significant effect on the yield and yield component barley. Application of nitrogen fertilizer one third at sowing plus two third at mid tillering gave the highest grain yield though it did not show significant differences with commonly practiced $1 / 2$ at sowing and $1 / 2$ at mid tillering.
\end{abstract}

Keywords: nitrogen fertilizer, split application timing, Nitisols, malt barley

DOI: $10.7176 / \mathrm{JNSR} / 10-1-05$

Publication date: January $31^{\text {st }} 2020$

\section{Introduction}

Barley one of the most important food crops predominantly grown from 1500 to $3500 \mathrm{~m}$ above sea level in Ethiopia (Lakew et al., 1996). It is the major food source in many North African countries. It is the staple food crops in Ethiopia. Barley assumes fourth position in total cereal production in the world after wheat, rice, and maize. In Ethiopia, It ranks fourth after tef, maize, sorghum in terms of cereal area production. It covers an area of about 951, 993 ha, but its national average yield is still low at 2.1 ton $\mathrm{ha}^{-1}$ (CSA, 2018). Barley serves as a major animal fodder, base malt for beer and certain other distilled beverages.

Nitrogen $(\mathrm{N})$ is the most important crop-yield limiting factor in the world, together with water (Mueller et al., 2012). Adoption of good $\mathrm{N}$ management strategies often result in large economic benefits to farmers. Among the plant nutrients, $\mathrm{N}$ plays a very important role in crop productivity (Amanullah et al., 2008a). $\mathrm{N}$ is frequently the most used and also the most costly mineral nutrient required for cereal production (Clark, 1990). Barley is very sensitive to insufficient $\mathrm{N}$ and very responsive to $\mathrm{N}$ fertilization. $\mathrm{N}$ is the key element in achieving consistently high yields in cereals. $\mathrm{N}$ is a constituent of many fundamental cell components such as nucleic acids, amino acids, enzymes, and photosynthetic pigments. Since $\mathrm{N}$ is a constituent of chlorophyll as well as the $\mathrm{CO}_{2}$ fixing enzyme Rubisco (also called the photosynthesis machinery), $\mathrm{N}$ content is indirectly a determinant of the rate of photosynthesis, dry matter accumulation, and economic yield (Evans 1983). The rate of uptake and partition of $\mathrm{N}$ is largely determined by supply and demand during various stages of plant growth. Soil $\mathrm{N}$ supply, must be high at tillering, stem elongation, booting, heading and grain filling requiring a greater amount of the development and growth of its reproductive organs. However, it has been estimated that $50 \%-70 \%$ of the N provided to the soil is lost due to volatilization, runoff, denitrification and leaching (Hodge et al., 2000).

Excessive $\mathrm{N}$ causes excessive vegetative growth, resulting in greatly increased danger of lodging, delayed maturity and greater susceptibility to diseases and pests. $\mathrm{N}$ application at proper dose has the most important effect in terms of increasing crop production. $\mathrm{N}$ is a key factor in achieving an optimum yield in cereals and in their growing period requires lot amount of absorbed N. Proper dose of $\mathrm{N}$ increased leaf area, tillers formation, leaf area index and leaf area duration and this increase led to much greater production of dry matter and grain yield. In order to obtain greatest advantage from the fertilizer use the fertilizer should not only be applied in optimum quantity at recommended rate but also at right time as timely $\mathrm{N}$ application is one of the agronomic technique which has helped considerably in increasing the $\mathrm{N}$ use efficiency (NUE).It is now very well established that for most crops $\mathrm{N}$ must be applied in two or three split doses coinciding with the crop growth stages when its requirement is high therefore, it is high time to assess the effect of time of application of the recommended $\mathrm{N}$ fertilizer to increase the fertilizer use efficiency in barley.

It is very important and crucial in crop production to nutrient supply is synchronized with plant demand in time and space throughout the growing season to get good yield and quality product acceptable along the value chain. Split applications reduce the exposure of $\mathrm{N}$ in saturated soils where the potential for losses such as leaching and denitrification are increased. Increasing fertilizer use efficiency is very important, particularly in developing countries where the fertilizer is very expensive driven mainly by increases in the price of natural gas. Hence, 
splitting $\mathrm{N}$ fertilizer application in order to follow the $\mathrm{N}$ requirements by the crop throughout the growing season is probably the best strategy to achieve high grain yields. Economical and appropriate method of application needs to be determined to enhance productivity and profit of the growers under given situation (Manzoor et al., 2006). Appropriate timing of $\mathrm{N}$ application and rates are crucial for meeting crop needs and indicate considerable opportunities for improving NUE. Limited research has been done on the effects of time of application in relation to improving grain yield of barely. Hence, this study was initiated to study the different $\mathrm{N}$ time of applications on the yield and yield components of barley, economic feasibility and agronomic $\mathrm{N}$ use efficiency.

\section{Materials and methods}

The experiment was conducted for 2 years (2015 and 2016 main cropping seasons) at Holeta Welmera wereda, West Shoa, on farmers field in the central highlands of Ethiopia The environment is seasonally humid and the soil type was reddish brown Eutric Nitisol (IUSS Working Group WRB, 2006). Holeta is located between $09^{\circ} 03^{\prime} \mathrm{N}$ latitude and $38^{\circ} 30^{\prime} \mathrm{E}$ longitude, $30 \mathrm{~km}$ west of Addis Ababa, at an altitude of about $2400 \mathrm{~m}$ above sea level. The long- term average annual rainfall is $1100 \mathrm{~mm}$, about $85 \%$ of which is received from June to September with the remainder from January to May. The average minimum and maximum air temperatures are $6.2^{\circ} \mathrm{C}$ and $22.1^{\circ} \mathrm{C}$ respectively.

\subsection{Experimental set-up and procedure}

The experiment was laid out randomized complete block design with three replications. The timings of $\mathrm{N}$ application were adjusted according to Zadoks decimal growth stage for barley (Zadoks et al., 1974) at the time when moisture is available for nutrient dissolution and absorption. Accordingly, treatments were comprised of eleven different times of $\mathrm{N}$ fertilizer application and a negative control $\mathrm{T}_{1}=1 / 2$ at planting $+1 / 2$ at mid tillering, $\mathrm{T}_{2}$ $=1 / 2$ at planting $+1 / 2$ at anthesis, $T_{3}=$ nil at planting $+1 / 2$ mid tillering $+1 / 2$ at anthesis, $T_{4}=$ nil at planting + full at mid tillering, $\mathrm{T}_{5}=$ nil at planting + full at anthesis, $\mathrm{T}_{6}=1 / 2$ at planting $+2 / 3$ at mid tillering, $\mathrm{T}_{7}=1 / 3$ at planting $+1 / 3$ mid tillering $+1 / 3$ at anthesis, $\mathrm{T}_{8}=$ nil at planting $+1 / 3$ mid tillering $+2 / 3$ at anthesis, $\mathrm{T}_{9}=2 / 3$ at planting $+1 / 3$ mid tillering, $T_{10}=2 / 3$ at planting $+1 / 3$ at anthesis, $T_{11}=$ full at planting and $T_{12}=$ negative control (without input). The same rate of $\mathrm{N}, 41 \mathrm{~N} \mathrm{~kg} \mathrm{ha}^{-1}$, was splitted and used in all cases. Urea was used as the source of $\mathrm{N}$. Phosphorus at the rate of $46 \mathrm{~kg} \mathrm{ha}^{-1}$ was applied to all plots at the time of sowing. Sowing took place at the onset of rainfall, with a seeding rate of $100 \mathrm{~kg} \mathrm{ha}^{-1}$ in early June. In each plot barley was sown at inter row spacing of $20 \mathrm{~cm}$ by drilling with a depth of at about $2-4 \mathrm{~cm}$. The recommended phosphorus fertilizer amount $\left(46 \mathrm{~kg} \mathrm{P} \mathrm{ha}^{-1}\right)$ was uniformly applied as triple super phosphate (TSP) to all plots at planting. $\mathrm{N}$ was applied after weeding in the presence of moisture to avoid the potential loss of $\mathrm{N}$ into the atmosphere. Other agronomic practices were applied based on research recommendations. The data were subjected to analysis of variance using the general linear model procedure of SAS statistical package version 9.3 (SAS Inc., 2012). Means of treatments were separated using the least significant difference (LSD) at 5\% level.

\section{Result and Discussion}

The effects of time $\mathrm{N}$ fertilizer application on malt barley grain and biomass yield and spike length were presented in table 1. Analysis of variance (ANOVA) result showed that time of $\mathrm{N}$ fertilizer application significantly $(\mathrm{p}<0.05)$ affected grain yield, biomass yield and spike length. Significantly higher grain yield was recorded by $1 / 3$ at planting \& 2/3 after 21-30 days of DAE though it did not show significant difference with that of $1 / 2$ at planting \& 1/2 after 21-30 DAE (Table 1). The lowest grain yield were recorded with the negative control where no $\mathrm{N}$ fertilizer was applied, where nitrogen was not applied and followed by application of $\mathrm{N}$ full at the time of anthesis. Significantly higher biomass yield was recorded by $1 / 3$ at planting $\& 2 / 3$ after 21-30 days of DAE though it did not showed significant difference with that of $1 / 2$ at planting $\& 1 / 2$ after $21-30 \mathrm{DAE}, 1 / 2$ at planting $+1 / 2$ at flower initiation, $1 / 3$ at planting $+2 / 3$ at mid tillering, Nil at planting $+1 / 3$ at mid tillering $+2 / 3$ at anthesis and full at planting (Table 1). The lowest biomass yield were recorded with the negative control where no $\mathrm{N}$ fertilizer was applied, where $\mathrm{N}$ was not applied and followed by application of $\mathrm{N}$ full at the time of anthesis.

Similarly, significantly longest spike length was obtained by $1 / 3$ at planting $+2 / 3$ at mid tillering though it did not show significant difference with application of $1 / 2$ at planting $+1 / 2$ mid tillering and full at planting (Table 1) which might have contributed to a higher grain yield obtained by T6 treatment. Shortest length of spike was observed in T12 treatment where $\mathrm{N}$ was not applied. ANOVA result also revealed that effect of time of split $\mathrm{N}$ applications on harvest index (ratio of the economic yield to the biological yield) was highly significant $(\mathrm{P}<0.01)$ (Table 1). Significantly higher harvest index was obtained with the application of $1 / 3$ at sowing $+2 / 3$ at mid tillering though there was no significant $1 / 2$ at planting $+1 / 2$ mid tillering, $1 / 2$ at planting $+1 / 2$ at flower initiation, nil at planting + full at mid tillering, $1 / 3$ at planting $+1 / 3$ at mid tillering $+1 / 3$ at anthesis, $2 / 3$ at planting $+1 / 3$ at mid tillering and full at planting. 
Table 1: Effect of time of $\mathrm{N}$ fertilizer application on yield and yield components of malt barley

\begin{tabular}{|c|c|c|c|c|}
\hline Time of $\mathrm{N}$ application & $\begin{array}{c}\text { Grain } \\
\text { Yield } \\
\left(\mathrm{kg} \mathrm{ha}^{-1}\right)\end{array}$ & $\begin{array}{c}\text { Biomass } \\
\text { yield } \\
\left(\mathrm{kg} \mathrm{ha}^{-1}\right) \\
\end{array}$ & $\begin{array}{r}\text { Spike } \\
\text { length } \\
(\mathrm{cm}) \\
\end{array}$ & $\begin{array}{c}\text { Harvest } \\
\text { index } \\
(\%) \\
\end{array}$ \\
\hline $\mathrm{T} 1=1 / 2$ at planting $+1 / 2$ mid tillering & 3895 & 9567 & 8.0 & 38.4 \\
\hline $\begin{array}{l}\mathrm{T} 2=1 / 2 \text { at planting }+1 / 2 \text { at flower } \\
\text { initiation }\end{array}$ & 3161 & 9667 & 7.5 & 38.0 \\
\hline $\begin{array}{l}\mathrm{T} 3=\text { nil at planting, } 1 / 2 \text { at mid tillering }+ \\
1 / 2 \text { at anthesis }\end{array}$ & 2687 & 9133 & 6.6 & 32.5 \\
\hline $\mathrm{T} 4=$ nil at planting + full at mid tillering & 2871 & 8733 & 7.3 & 36.5 \\
\hline $\mathrm{T} 5=$ Nil at planting + full at anthesis & 2830 & 9333 & 6.3 & 32.4 \\
\hline $\mathrm{T} 6=1 / 3$ at planting $+2 / 3$ at mid tillering & 4110 & 10833 & 8.4 & 39.9 \\
\hline $\begin{array}{l}\mathrm{T} 7=1 / 3 \text { at planting }+1 / 3 \text { at mid tillering } \\
+1 / 3 \text { at anthesis }\end{array}$ & 3387 & 8833 & 7.6 & 36.2 \\
\hline $\begin{array}{l}\text { T8 }=\text { Nil at planting }+1 / 3 \text { at mid tillering } \\
+2 / 3 \text { at anthesis }\end{array}$ & 2782 & $9750 \mathrm{a}$ & 7.8 & 33.4 \\
\hline $\mathrm{T} 9=2 / 3$ at planting $+1 / 3$ at mid tillering & 3436 & $9900 \mathrm{a}$ & 7.5 & 39.0 \\
\hline $\mathrm{T} 10=2 / 3$ at planting $+1 / 3$ at anthesis & 2991 & 9333 & 7.4 & 33.0 \\
\hline $\mathrm{T} 11=$ full at planting & 2968 & 10050 & 7.8 & 35.7 \\
\hline T12=Negative Control (No input) & 1594 & 7767 & 6.1 & 31.9 \\
\hline $\mathrm{LSD}_{0.05}$ & 558 & 9567 & 0.68 & 4.8 \\
\hline Significance level & $* * *$ & $*$ & $* * *$ & $* *$ \\
\hline $\mathrm{CV}(\%)$ & 15.2 & 13.6 & 8.0 & 11.7 \\
\hline
\end{tabular}

Time of $\mathrm{N}$ split-applications has also brought economic advantage on malt barley production as shown table 2. The economic analysis showed that split $\mathrm{N}$ fertilizer application $1 / 3$ at sowing $+2 / 3$ at mid tillering was the right time of $\mathrm{N}$ application due to the fact that it gave the highest net economic benefit (Table 2). Time of $\mathrm{N}$ split application of $1 / 3$ at sowing $+2 / 3$ at mid tillering gave a $5 \%$ and $27 \%$ monitory advantage in Ethiopian Birr over the recommended $\mathrm{N}$ application of $1 / 2$ at sowing $+1 / 2$ at mid tillering and $1 / 3$ at sowing $+1 / 3$ at mid tillering $+1 / 3$ at anthesis, respectively. Application of $1 / 3 \mathrm{~N}$ at sowing $+2 / 3$ at mid tillering was more economically beneficial than other-split-applications. N Use Efficiency (NUE) expressed as grain production per unit of $\mathrm{N}$ applied, indicated that malt barley had the highest NUE when the $\mathrm{N}$ was applied in split of $1 / 3$ at sowing $+2 / 3$ at mid tillering (Table 2). N Use Efficiency (NUE) expressed as grain production per unit of $\mathrm{N}$ applied, indicated that malt barley had the highest NUE when the $\mathrm{N}$ was applied in split of $1 / 3$ at sowing $+2 / 3$ at mid tillering (Table 3 ).

Table 2: Economic analysis for split time of $\mathrm{N}$ fertilizer application on malt barley

\begin{tabular}{llcccc}
\hline No. & Treatments & $\begin{array}{c}\text { Grain } \\
\text { Yield } \\
\left(\mathrm{kg} \mathrm{ha}^{-1}\right)\end{array}$ & $\begin{array}{c}\text { Total } \\
\text { variable } \\
\text { cost }\end{array}$ & $\begin{array}{c}\text { Gross } \\
\text { profit }\end{array}$ & $\begin{array}{c}\text { Net } \\
\text { benefit }\end{array}$ \\
\hline T1 & $1 / 2$ at sowing $+1 / 2$ mid tillering & 3895 & 4000 & 31160 & 27160 \\
T2 & $1 / 2$ at sowing $+1 / 2$ at flower initiation & 3161 & 4000 & 25288 & 21288 \\
T3 & nil at sowing, $1 / 2$ at mid tillering $+1 / 2$ at anthesis & 2687 & 3700 & 21496 & 17796 \\
T4 & nil at sowing + full at mid tillering & 2871 & 3700 & 22968 & 19268 \\
T5 & Nil at sowing + full at anthesis & 2830 & 3700 & 22640 & 18940 \\
T6 & $1 / 3$ at sowing $+2 / 3$ at mid tillering & 4110 & 4300 & 32880 & 28580 \\
T7 & $1 / 3$ at sowing $+1 / 3$ at mid tillering $+1 / 3$ at anthesis & 3387 & 4300 & 27096 & 22796 \\
T8 & Nil at sowing $+1 / 3$ at mid tillering $+2 / 3$ at anthesis & 2782 & 4000 & 22256 & 18256 \\
T9 & 2/3 at sowing $+1 / 3$ at mid tillering & 3436 & 4000 & 27488 & 23488 \\
T10 & 2/3 at sowing $+1 / 3$ at anthesis & 2991 & 4000 & 23928 & 19928 \\
T11 & full at sowing & 2968 & 4000 & 23744 & 19744 \\
\hline
\end{tabular}


Table 3: Economic analysis for split time of $\mathrm{N}$ fertilizer application on malt barley

\begin{tabular}{llc}
\hline No. & Treatments & Agronomic N Use Efficiency \\
\hline T1 & $1 / 2$ at sowing $+1 / 2$ mid tillering & 56.1 \\
T2 & $1 / 2$ at sowing $+1 / 2$ at flower initiation & 38.2 \\
T3 & nil at sowing, $1 / 2$ at mid tillering $+1 / 2$ at anthesis & 26.7 \\
T4 & nil at sowing + full at mid tillering & 31.1 \\
T5 & Nil at sowing + full at anthesis & 30.1 \\
T6 & $1 / 3$ at sowing $+2 / 3$ at mid tillering & 61.4 \\
T7 & $1 / 3$ at sowing $+1 / 3$ at mid tillering $+1 / 3$ at anthesis & 43.7 \\
T8 & Nil at sowing $+1 / 3$ at mid tillering $+2 / 3$ at anthesis & 29.0 \\
T9 & $2 / 3$ at sowing $+1 / 3$ at mid tillering & 44.9 \\
T10 & $2 / 3$ at sowing $+1 / 3$ at anthesis & 34.1 \\
T11 & full at sowing & 33.5 \\
\hline
\end{tabular}

\subsection{Conclusion}

Malt barley growth yield and yield components were significantly affected by time split $\mathrm{N}$ fertilizer application. From the present study it is evident that time of split $\mathrm{N}$ applications generally improved grain yield of barley. Time of split $\mathrm{N}$ fertilizer application $1 / 3$ at sowing and $2 / 3$ at mid tillering stage brought about the higher grain yield, aboveground biomass yield, spike length and harvest index when compared with other split $\mathrm{N}$ time applications. Application of $\mathrm{N}$ fertilizer $1 / 3$ at sowing plus $2 / 3$ at mid tillering gave the highest grain yield though it did not show significant differences with commonly practiced $1 / 2$ at sowing and $1 / 2$ at mid tillering. Further investigations should be done to know quality aspect of malt with respect to time of $\mathrm{N}$ applications in addition to the climatic effect.

\section{References}

Amanullah, R.A., Khattak and S.K. Khalil. 2008a. Effects of plant density and N on phenology and yield of cereal. Plant. Nut. J., 32: 246-260.

Ayoub, M., S. Guertin, S. Lussier and D.L. Smith. 1994. Timing and levels of nitrogen fertility effects on spring wheat. Crop Sci., 34: 748-750.

Bremner, J.M. and Mulvaney C.S. 1982. Nitrogen total. In: Page AL, editor. Methods of soil analysis, part 2. Chemical and microbiological properties. 2nd ed. Madison (WI): American Society of Agronomy; p. 595624.

Clark, R.B. 1990. Physiology of cereals for mineral nutrient uptake, use and efficiency. In Crops as Enhancers of Nutrient Use, V.C. Baligar, and R.R. Duncan (eds.). San Diego: Academic Press. p 131-209.

(CSA) Central Statistical Agency. 2018. Report on area and production of major crops (private peasant holdings, Meher season) for 2017/2018. Statistical Bulletin 586. Addis Ababa, Ethiopia.

Evans, J. R. 1983. Nitrogen and photosynthesis in the flag leaf of wheat (Triticum aestivum L.). Plant Physiol. 72: 297302.

Hatfield, J.L. and Prueger, J.H. 2004. Nitrogen Over-use, Under-use, and Efficiency. "New directions for a diverse planet". Proceedings of the 4th International Crop Science Congress, 26 Sep - 1 Oct 2004, Brisbane, Australia. pp 21-29.

Hodge, A..Robinson, D., Fitter, A. 2000. Are microorganisms more effective than plants at competing for nitrogen? Trends Plant Science 5, 304-308.

Lakew, B., Gebre, H., Alemayehu, F. 1996. Barley production and research in Ethiopia. In: Gebre G, van Leur J, editors. Barley research in Ethiopia: past work and future prospects. Addis Ababa: IAR/ICARDA; p. 1-8.

Manzoor, Z., R.I. Ali, T.H., Awan, N., Khalid and Ahmad, M. 2006. Appropriate time of nitrogen application to fine rice, Oryza sativa. Journal of Agricultural Resources, 44(4).

Mueller, N.D., Gerber, J.S., Johnston, M., Ray, D.K., Ramankutty, N., Foley, J.A. 2012. Closing yield gaps through nutrient and water management. Nature 490, 254-257.

SAS Institute. 2013. SAS User's Guide, Version 9.3; SAS Institute: Cary, NC, USA. 